\title{
Arthrinic Acid, a Novel Antifungal Polyhydroxyacid from Arthrinium phaeospermum
}

\author{
Stephen Bloor
}

Received: February 19, 2008 / Accepted: July 23, 2008

(C) Japan Antibiotics Research Association

\begin{abstract}
Arthrinic acid was isolated from solid state fermentations of the fungus Arthrinium phaeospermum. The structure of arthrinic acid was determined to be $(6 E, 10 E, 14 E, 18 E, 20 E)-2,3,5,9,13,17$-hexahydroxy-20(hydroxymethyl)-14,16,18,22,24-pentamethylhexacosa6,10,14,18,20-pentaenoic acid from NMR spectroscopic studies.
\end{abstract}

Keywords antifungal, arthrinic acid, Arthrinium, structure elucidation, fungus

\section{Introduction}

In our continuing study of New Zealand microbes for agrochemical activity, we have been able to access a large number of fungi associated with plants. Such fungi have proven to be particularly rich sources of activity in our screens for fungicidal, herbicidal and insecticidal metabolites. Thanks to a high throughput isolation and miniaturized assay system it has been possible to screen many thousands of diverse fungi and to focus on those where the activity is due to novel compounds. In this note we describe the structure elucidation of one such novel compound isolated from a fungus, Arthrinium phaeospermum, sourced from a collection held at Landcare Research New Zealand. Extracts from solid state fermentations of $A$. phaeospermum showed good antifungal activity. This activity was tracked, through a bioassayguided separation, to a single compound, 1, a new hepta-

S. J. Bloor (Corresponding author): Biodiscovery New Zealand Ltd., PO Box 31-310, Lower Hutt, New Zealand.

E-mail: sbloor@biodiscovery.co.nz hydroxy carboxylic acid.

\section{Results and Discussion}

A molecular formula of $\mathrm{C}_{32} \mathrm{H}_{54} \mathrm{O}_{9}$ was deduced from ${ }^{13} \mathrm{C}-\mathrm{NMR}$ and HR-MS data (HR-MS (M-H) 581.3708, calcd. for $\mathrm{C}_{32} \mathrm{H}_{53} \mathrm{O}_{9}$ 581.3684). An acid group and five double bonds accounted for all the degrees of unsaturation. 1 was readily converted to a monomethyl ester (diazomethane) and contains 6 methyl groups, two of which are located on double bonds. Thus $\mathbf{1}$ is a linear structure with seven hydroxyl groups. While this high degree of functionalisation lead to relatively well separated signals in the NMR spectra, there were still a number of overlapped signals which overall posed a challenging problem for structure solution.

Using the $\mathrm{H}-\mathrm{H}$ and $\mathrm{C}-\mathrm{H}$ connection NMR experiments (HMBC, HMQC), the molecule was assembled as follows. Starting at the "non-polar" end the terminal dimethylpentyl group containing three of the methyl groups was readily determined. This unit could be attached to a hydroxy-methyl substituted double bond unit based on $\mathrm{H}-\mathrm{H}$ NMR connections between $\mathrm{H}-21$ and $\mathrm{H}-22$, and between $\mathrm{H}-$ 21 and the hydroxyl-methylene protons, H-30. The chain was extended by a further double bond evidenced by long range $\mathrm{C}-\mathrm{H}$ coupling between $\mathrm{H}-21$ and $\mathrm{C}-19$. One of the two olefinic methyls is located on this second double bond. Further elongation through an $\mathrm{H}-\mathrm{C}$ coupling between $\mathrm{H}-19$ and $\mathrm{C}-17$ and then $\mathrm{H}-\mathrm{H}$ coupling permitted the addition of the $\mathrm{C}-17$ to $\mathrm{C}-14$ portion of the molecule. Moving to the "polar" end of the molecule, only one long range $\mathrm{C}-\mathrm{H}$ coupling from $\mathrm{H}-2$ to the acid carbon was evident. The coupling between $\mathrm{H}-2$ and $\mathrm{H}-3$ is small and further connections at this end of the molecule relied upon 


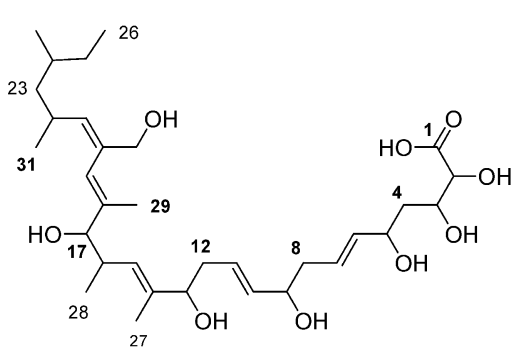

Arthrinic acid (1)

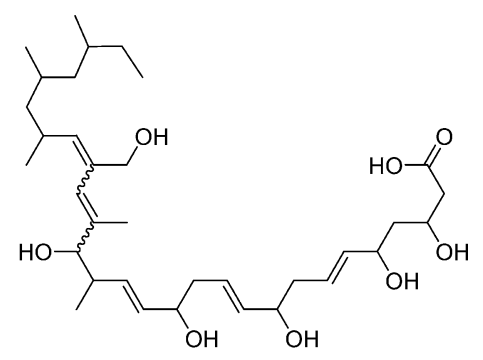

Phomenoic acid coupling between the well separated $\mathrm{H}-4$ signals and $\mathrm{H}-3$ and $\mathrm{H}-5$ and $\mathrm{C}-2,-3$ and -4 . Thus this polar end of the molecule comprises a 2,3,5-tri-hydroxy pentanoic acid. Further elongation of this polar end substructure by an eight carbon section comprising two repeated 4 carbon units (a hydroxymethine, a disubstituted double bond and a methylene) resulted from the deconvolution of a set of twinned NMR signals. This addition of the C-6 to C13 portion to the trihydroxy acid meant that all the carbons in the structure were accounted for in the two substructures. These substructures could then be joined, based on a long range $\mathrm{C}-\mathrm{H}$ coupling between $\mathrm{C}-13$ and $\mathrm{H}-15$ to complete the structure shown, i.e. 2,3,5,9,13,17-hexahydroxy-20(hydroxymethyl)-14,16,18,22,24-pentamethylhexacosa6,10,14,18,20-pentaenoic acid. This structure, with a highly hydroxylated acid end and a more aliphatic "tail", is very similar to phomenoic acid $[1,2]$. This kind of lipid-mimic structure is also seen in other bioactive microbial metabolites such a khafrefungin [3] and the sphingofungins [4].

Based on NMR data all of the double bonds in $\mathbf{1}$ are $E$ configurated. The coupling constants for the disubstituted double bonds are $16 \mathrm{~Hz}$ and NOE's (NOESY experiment) between $\mathrm{H} 15$ and $\mathrm{H}-13, \mathrm{H} 19$ and $\mathrm{H} 17$ and $\mathrm{H}-21$ and $\mathrm{H}-30$ show the three trisubstituted double bonds also share this configuration. There are no NOE's between the two olefinic methyls and any of the olefinic protons.

Acetylation of the methyl ester of $\mathbf{1}$ formed a heptaactetate. The extra separation of the downfield signals in the ${ }^{1} \mathrm{H}-\mathrm{NMR}$ of the acetate (especially those for H-3, H-9 and $\mathrm{H}-13$ ) confirmed the connections and $E$-configuration of the double bonds.

For comparison purposes the structure of the closely related phomenoic acid (double bond stereochemistry unknown) is also shown with the all- $E$ configuration although it is usually drawn with the C-20 double bond as $Z$.

Arthrinic acid showed broad-spectrum antifungal activity against a range of agrochemical fungal targets (MIC approx. $50 \mu \mathrm{g} / \mathrm{ml}$ vs. Botrytis cinerea, Rhizopus stolonifer and Diplodia pinea).

\section{Experimental}

\section{General}

NMR experiments were performed on a Bruker AC300 instrument or Varian 500 instrument. All NMR spectra were recorded in $\mathrm{CD}_{3} \mathrm{OD}$. Analytical HPLC-MS chromatograms were run on an Agilent 1100 MSD system, with ES-MS in both negative and positive ion mode using a Agilent Zorbax Eclipse XDB-C8 column $(2.1 \times 100 \mathrm{~mm})$. Preparative HPLC was performed on a larger XDB-C8 column $(21.2 \times 150 \mathrm{~mm})$ using a Waters 600 system with a 994 PDA detector. Acetonitrile, water and formic acid mixtures were used for HPLC. HR-MS were performed on a Waters Q-TOF Premier ${ }^{\mathrm{TM}}$ Tandem Mass Spectrometer operating in negative ion mode.

\section{Cultivation and Isolation}

The culture of $A$. phaeospermum was obtained from the Landcare Research NZ International Collection of Microorganisms from Plants (ICMP collection no. 13908) and was originally isolated from Passiflora edulis Sims from the Waipapa area of New Zealand. Fungal cultures for largescale extraction were grown on kibbled wheat in $5 \times 200 \mathrm{ml}$ plastic bottles. Each bottle contained fifty grams of sterile kibbled wheat was hydrated to $80 \% \mathrm{w} / \mathrm{v}$ with $32 \mathrm{ml}$ of water and an $8.0 \mathrm{ml}$ liquid culture of the fungus grown for one week in a potato-malt extract medium. Fungal cultures were prepared for extraction after 3 weeks incubation at $25^{\circ} \mathrm{C}$.

The whole culture was extracted with $\mathrm{MeOH}$ and concentrated. The residue was suspended in water and chromatographed on RP silica $(40 \sim 63 \mu \mathrm{m})$ using a stepwise gradient of $100 \%$ water through to $100 \% \mathrm{MeOH}$ to give twelve fractions. The fractions containing 1 ( $0.45 \mathrm{~g}$, eluted $80 \sim 90 \% \mathrm{MeOH}$ ) were combined and subjected to 
preparative RP HPLC, using a gradient of $40: 60$ through to $52: 48 \mathrm{CH}_{3} \mathrm{CN}$ : water (with $1.0 \%$ formic acid) to yield $55 \mathrm{mg}$ of 1 .

\section{Physico-chemical Properties}

Arthrinic acid ((6E,10E,14E,18E,20E)-2,3,5,9,13,17hexahydroxy-20-(hydroxymethyl)-14,16,18,22,24-pentamethylhexacosa-6,10,14,18,20-pentaenoic acid).

Off-white powder. Mp: $99.5 \sim 101.5^{\circ} \mathrm{C}$; UV $\lambda^{\mathrm{MeOH}} \mathrm{nm}$ end, $225(\mathrm{sh}) ;[\alpha]_{\mathrm{D}}^{20}+8.8(c 0.7, \mathrm{MeOH})$; ES-MS (pos.

Table $1{ }^{1} \mathrm{H}$ - and ${ }^{13} \mathrm{C}-\mathrm{NMR}$ data of arthrinic acid (1) in $\mathrm{CD}_{3} \mathrm{OD}$

\begin{tabular}{|c|c|c|}
\hline No. & $\delta_{\mathrm{H}}$ & $\delta_{\mathrm{C}}$ \\
\hline 1 & & 176.65 \\
\hline 2 & $4.08(1 \mathrm{H}, \mathrm{d}, 2.5)$ & 75.06 \\
\hline 3 & $4.05(1 \mathrm{H}, \mathrm{m})$ & 71.85 \\
\hline $4 a$ & $1.88(1 \mathrm{H}, \mathrm{ddd}, 14,8,7)$ & 40.72 \\
\hline $4 b$ & $1.72(1 \mathrm{H}, \mathrm{ddd}, 14,7,5)$ & \\
\hline 5 & $4.23(1 \mathrm{H}, \mathrm{dt}, 7,7)$ & 72.01 \\
\hline 6 & $5.52(1 \mathrm{H}, \mathrm{dd}, 15,7)$ & 136.77 \\
\hline 7 & $5.70(1 \mathrm{H}, \mathrm{dt}, 15,7)$ & 129.5 \\
\hline 8 & $2.26(2 \mathrm{H}, \mathrm{m})$ & 40.72 \\
\hline 9 & $4.05(1 \mathrm{H}, \mathrm{m})$ & 73.72 \\
\hline 10 & $5.55(1 \mathrm{H}, \mathrm{dd}, 15,7)$ & 136.19 \\
\hline 11 & $5.61(1 \mathrm{H}, \mathrm{dt}, 15,7)$ & 129.5 \\
\hline 12 & $2.30(2 \mathrm{H}, \mathrm{m})$ & 39.22 \\
\hline 13 & $4.02(1 \mathrm{H}, \mathrm{m})$ & 79.16 \\
\hline 14 & & 139.08 \\
\hline 15 & $5.31(1 \mathrm{H}, \mathrm{d}, 9)$ & 132.03 \\
\hline 16 & $2.65(1 \mathrm{H}, \mathrm{ddq}, 9,9,7)$ & 37.45 \\
\hline 17 & $3.77(1 \mathrm{H}, \mathrm{d}, 9)$ & 84.04 \\
\hline 18 & & 141.78 \\
\hline 19 & $5.86(1 \mathrm{H}, \mathrm{s})$ & 126.59 \\
\hline 20 & & 136.89 \\
\hline 21 & $5.26(1 \mathrm{H}, \mathrm{dd}, 10,1)$ & 135.76 \\
\hline 22 & $2.42(1 \mathrm{H}, \mathrm{m})$ & 32.56 \\
\hline $23 a$ & $1.30(1 \mathrm{H}, \mathrm{m})$ & 46.58 \\
\hline $23 b$ & $1.04(1 \mathrm{H}, \mathrm{m})$ & \\
\hline 24 & $1.30(1 \mathrm{H}, \mathrm{m})$ & 33.76 \\
\hline $25 a$ & $1.25(1 \mathrm{H}, \mathrm{m})$ & 31.6 \\
\hline $25 b$ & $1.11(1 \mathrm{H}, \mathrm{m})$ & \\
\hline 26 & $0.84(3 \mathrm{H}, \mathrm{t}, 7.3)$ & 12.2 \\
\hline 27 & $1.66(3 \mathrm{H}, \mathrm{s})$ & 12.13 \\
\hline 28 & $0.86(3 \mathrm{H}, \mathrm{d}, 7)$ & 20.29 \\
\hline 29 & $1.66(3 \mathrm{H}, \mathrm{s})$ & 13.59 \\
\hline 30 & $4.00(2 \mathrm{H}, \mathrm{s})$ & 67.44 \\
\hline 31 & $0.96(3 \mathrm{H}, \mathrm{d}, 6.6)$ & 24.02 \\
\hline 32 & $0.81(3 \mathrm{H}, \mathrm{d}, 6.3)$ & 21.82 \\
\hline
\end{tabular}

mode) $m / z 605[\mathrm{M}+\mathrm{Na}]^{+}, 547\left[\mathrm{M}-2\left(\mathrm{H}_{2} \mathrm{O}\right)+\mathrm{H}\right]^{+}, 529$ $\left[\mathrm{M}-3\left(\mathrm{H}_{2} \mathrm{O}\right)+\mathrm{H}\right]^{+}, 511\left[\mathrm{M}-4\left(\mathrm{H}_{2} \mathrm{O}\right)+\mathrm{H}\right]^{+}$; (neg. mode) $\mathrm{m} / \mathrm{z} 581[\mathrm{M}-\mathrm{H}]^{-}$.

\section{Heptaacetate Methyl Ester of Arthrinic Acid}

Arthrinic acid was converted to the methyl ester by addition of an excess of (trimethylsilane)diazomethane. Overnight treatment of the methyl ester with acetic anhydride and dimethyl-amino pyridine yielded the heptaacetate. The acetate was purified by preparative RP HPLC, using a gradient of $60: 40$ through to $95: 5 \mathrm{CH}_{3} \mathrm{CN}$ : water (with $1.0 \%$ formic acid). ES-MS (pos. mode) $\mathrm{m} / z 913[\mathrm{M}+\mathrm{Na}]^{+}$; ${ }^{1} \mathrm{H}-\mathrm{NMR}\left(500 \mathrm{MHz}, \mathrm{CD}_{3} \mathrm{OD}\right) \delta 5.92(1 \mathrm{H}, \mathrm{s}, \mathrm{H}-19), 5.68$ (1H, dt, H-7), 5.62 (1H, dt, H11), $5.55(1 \mathrm{H}, \mathrm{dd}, \mathrm{H}-10)$, $5.51(1 \mathrm{H}, \mathrm{dd}, \mathrm{H}-6), 5.37$ (1H, ddd, H-3), $5.33(1 \mathrm{H}$, br d, H-21), 5.30 (1H, brd, H-15), 5.24 (1H, dd, H-5), $5.21(1 \mathrm{H}$, dd, H-9), 5.15 (1H, d, H-2), 5.12 (1H, dd, H-13), 5.02 (1H, d, H-17), 4.56 (1H, d, H-30a), 4.49 (1H, d, H-30b), 2.85 (1H, ddq, H-16), 2.38 (2H, m, H-8, H-12), 2.17 $\left(3 \mathrm{H}, \mathrm{s}, \mathrm{OCOCH}_{3}\right), 2.05\left(3 \mathrm{H}, \mathrm{s}, \mathrm{OCOCH}_{3}\right), 2.03(6 \mathrm{H}$, $\left.\mathrm{s}, 2 \times \mathrm{OCOCH}_{3}\right), 2.02\left(3 \mathrm{H}, \mathrm{s}, \mathrm{OCOCH}_{3}\right), 2.01(3 \mathrm{H}, \mathrm{s}$, $\left.\mathrm{OCOCH}_{3}\right), 1.98\left(3 \mathrm{H}, \mathrm{s}, \mathrm{OCOCH} \underline{-}_{3}\right), 1.7(3 \mathrm{H}, \mathrm{d}, \mathrm{H}-27), 1.68$ (3H, d, H29), 0.95 (3H, d, H-28,), 0.93 (3H, d, H-31), 0.87 (3H, t, H-26), 0.8 (3H, d, H-27).

Acknowledgment This work was supported by a New Zealand Foundation for Research Science and Technology grant (contract number BIDX0201) and Syngenta plc. Maureen Fletcher, Landcare New Zealand, provided the fungal isolate.

\section{References}

1. Devys M, Ferezou J-P, Topgi R, Barbier M, Bousquet J-F, Kollman A. Structure and biosynthesis of phomenoic acid, an antifungal compound isolated from Phoma lingam Tode. J Chem Soc Perkin Trans I: 2133-2137 (1984)

2. Topgi R, Devys M, Bousquet J-F, Kollmann A, Barbier M. Phomenoic acid and phomenolactone, antifungal substances from Phoma lingam (Tode) Desm.: kinetics of their biosynthesis, with an optimization of the isolation procedures. Appl Environ Microbiol 53: 966-968 (1987)

3. Mandala SM, Thornton RA, Rosenbach M, Milligan J, Garcia-Calvo M, Bull HG, Kurtz MB. Khafrefungin, a Novel Inhibitor of Sphingolipid Synthesis. J Biol Chem 272: 32709-32714 (1997)

4. Horn WS, Smith JL, Bills GF, Raghoobar SL, Helms GH, Kurtz MB, Marrinan JA, Frommer BR, Thornton RA, Mandala SM. Sphingofungins E and F: Novel serinepalmitoyltransferase inhibitors from Paecilomyces variiotii. J Antibiot 47: 376-379 (1992) 